\title{
New Zealand and Maori land trusts
}

\section{Juliet Chevalier-Watts*}

\section{Abstract}

New Zealand, as in other jurisdictions, has a range of recognized trusts that would be familiar to many. These include express trusts, resulting trusts, constructive trusts, and charitable trusts. Perhaps more unfamiliar, at least to those outside New Zealand, are trusts that are unique to the New Zealand legal landscape and that are specific to Maori land. This article explores the relevance, and importance, of such trusts within New Zealand-Aotearoa. In doing so, the author considers a number of these Maori land trusts, and critically evaluates a range of issues, which includes governance; conflict of interest; unsatisfactory conduct; and dysfunction. While Maori land trusts are subject to the general laws of trust, it can be seen from the article how valuable such trusts are in recognizing and protecting Maori interests. As such, their unique nature reflects their fundamental relevance in indigenous culture, and also generally as an effective management tool for much Maori land.

\section{Introduction}

There are several types of equitable interest in property, trusts being just one of them, and it is likely that trusts are the best known of the types of equitable interest. Other equitable interests include equitable leases, and equitable mortgages. With respect to trusts, the beneficiary, who is the equitable interest holder, has the right to compel the legal owner, the trustee to recognize, and give effect to the beneficiary's interest. The nature of the interest held by the beneficiary will depend on the terms of the trust. ${ }^{1}$ There is also a range of trusts that are recognized in New Zealand, like other jurisdictions, which include express trusts, resulting trusts, constructive trusts, and charitable trusts.

In addition to these recognized trusts, New Zealand has a unique range of trusts specific to Maori land. The Maori Land Court has exclusive jurisdiction to constitute the five types of Maori trusts, and these are authorized by the Te Ture Whenua Maori Act 1993 (Maori Land Act 1993), and are as follows:

Ahu Whenua-this is the main form of trust where the total freehold interest in Maori land or General land owned by Maori is vested in a trust/trustee by the Maori Land Court, and is utilized to promote and facilitate the use and administration of the land for those who are beneficial owners of the land. This type of trust is the equivalent of section 438 trust under the now repealed Maori Affairs Act $1953 .^{2}$

Whanau-these are share-managed type trusts. Such trusts were introduced under the Act and under them, land interests of the living or the deceased owner are vested in trustees, generally family members, and no further succession or fragmentation occurs. ${ }^{3}$

Whenua Topu—such trusts are similar to the ahu whenua trusts, in that they are land-management

\footnotetext{
* Juliet Chevalier-Watts, Associate Dean Research, Senior Lecturer in Law, Te Piringa - Faculty of Law, University of Waikato, New Zealand. Tel: +64 (0)7 856

1. Andrew S Butler, 'Equitable Proprietery Interests' in Andrew Butler (ed), Equity and Trusts in New Zealand (ThomsonReuters 2009) 23-24.

2. Richard Boast and others, Maori Land Law (2nd edn, LexisNexis 2004) 163.

3. ibid; 'whanau' means extended family group <http://www.teara.govt.nz/en/tribal-organisation/page-4> accessed 17 December2015
} 2889. 
trusts, but whenua topu trusts operate to facilitate the use and administration of the land in the interests of iwi ${ }^{4}$ or hapu, ${ }^{5}$ as opposed to those with a beneficial interest in the land. ${ }^{6}$

Kai Tiaki-where real or personal property owned by a Maori person under disability is vested by the Maori Land Court in a trustee(s). ${ }^{7}$ This is the only trust that relates solely to individuals. Such trusts can work under the umbrella of whanau, putea, ahu whenua or whenua topu trusts, or Maori incorporations. ${ }^{8}$

Putea - these are share management type trusts, which are designed to manage impractical, or undesirable, limited value interests, or to manage interests where those with beneficial interests are not known. ${ }^{9}$ Limited numbers of these trusts have been created.

\section{New Zealand has a unique range of trusts spe- cific to Maori land}

It is worthwhile noting that Maori land can be held on trust by other means. Maori are at liberty to utilize other forms of trust to hold land, thus drawing on other forms of trust law. ${ }^{10}$

To contextualize these types of unique trusts within the New Zealand legal landscape, it is worthwhile setting out, briefly, the historical and modern-day positions of the Crown within New Zealand-Aotearoa.

By Article 1 of the Treaty of Waitangi, ${ }^{11}$ a number of Maori chiefs purported to cede to the Crown absolutely all of their rights and powers of sovereignty.
By Article 2, the Crown confirmed and guaranteed to the, inter alia, Maori chiefs and tribes the full and undisturbed possession of their land and possessions, as long as they wished it. The Treaty was written in Maori and English. It is acknowledged that there has been difficulty in reconciling the two language versions, meaning that there still to this day is uncertainty as to what was intended to be ceded, and what was intended to be reserved. ${ }^{12}$ This is expressed eloquently by Cooke P in New Zealand Maori Council v Attorney-General: ${ }^{13}$

The principles of the Treaty are to be applied, not the literal words. As is well known, the English and Maori texts in the first schedule to the Treaty of Waitangi Act 1975 are not translations the one of the other and do not necessarily convey precisely the same meaning.

There is continuing debate over the effect of the Treaty, and it is acknowledged that 'Treaty issues are a study in themselves and the literature is voluminous. ${ }^{, 14}$ It is not the intention of this article to explore these issues further. The reality however is that the Treaty is of fundamental importance and relevance in New Zealand society. When the Treaty of Waitangi Act 1975 was enacted, it changed the practical effect of the Treaty, if not its status. The Act established the Waitangi Tribunal, which makes recommendations on claims relating to the application of the Treaty, and to determine of relevant matters are consistent with the principles of the Treaty. ${ }^{15}$ When the Crown assumed sovereignty over New Zealand, Maori customary title was extinguished, along with

4. Iwi: a Maori tribe descended from a common-named ancestor(s), usually comprised of a number of hapu; see $<$ http://ww.tkm.govt.nz/glossory $>$ accessed 17 December2015

5. Hapu—a sub tribe; most iwi are comprised of two or more hapu; see <http://ww.tkm.govt.nz/glossory $>$ accessed 17 December2015

6. Boast and others (n 2).

7. ibid.

8. 'Maori Land Trusts' (Ministry of Justice 2010) 11 <http://www.justice.govt.nz/courts/maori-land-court/documents/publications/booklets/ Maori\%20Land\%20Trusts.pdf> accessed 17 December2015

9. Jacinta Ruru, 'Equity and Maori' in Andrew Butler (ed), Equity and Trusts in New Zealand (ThomsonReuters 2009$) 1253$.

10. ibid 1251.

11. See <http://www.nzhistory.net.nz/politics/treaty/the-treaty-in-brief> accessed 17 December2015: 'The Treaty of Waitangi is New Zealand's founding document. It takes its name from the place in the Bay of Islands where it was first signed, on 6 February 1840. This day is now a public holiday in New Zealand. The Treaty is an agreement, in Māori and English, that was made between the British Crown and about 540 Māori rangatira (chiefs).'

12. GW Hinde and others, Principles of Real Property Law (2nd edn, LexisNexis 2014) 26

13. New Zealand Maori Council v Attorney-General [1987] 1 NZLR 641, 662 (CA).

14. Hinde and others (n 12) 27.

15. ibid. 
acquisition of land from Maori land owners. This fell into two distinct periods: ${ }^{16}$

The first commencement on the assumption of... Sovereignty in 1840 and continued until the establishment of the Maori Land Court in 1865; and the second has lasted from that time until the present day.

From 1840 until 1865, in other words, prior to the Maori Land Court, Crown agents usually negotiated directly with Maori for the purchase or acquisition of land. In 1865, the Māori Land Court was established, although it was originally named the Native Land Court. Under the Māori Purposes Act 1947, it became the Māori Land Court. Its original purpose was to translate customary Māori land claims into legal land titles recognizable under English Law. In 1993, the Te Ture Whenua Māori Act was enacted as a culmination of work to assist with the use and development of Maori land, to enable some flexibility in land management, including trusts. ${ }^{17}$ In other words, the Act was created to promote the retention, use, development, and control of Maori customary land and Maori freehold land. ${ }^{18}$ One of the benefits of this Act was to expand the court's jurisdiction to allow it to hear cases on all matters pertaining to Māori land. ${ }^{19}$

The Māori Land Court today, through Te Ture Whenua Māori Act 1993, endeavours to promote the retention, use, development, and control of Māori land as taonga tuku iho by Māori owners, their whānau, their hapū, and their descendants. ${ }^{20}$

Section 129(1) of the Te Ture Whenua Act, provides that for the purposes of the Act, all land in New Zealand has one of the following statuses: ${ }^{21}$
- Maori customary land;

- Maori freehold land;

- General land owned by Maori;

- Crown land; and

- Crown land reserved for Maori.

Section 131 of the Act gives the Maori Land Court jurisdiction to determine and declare the particular status of a parcel of land.

As mentioned earlier, the Act provides for five types of Maori trusts that relate mainly to Maori land, and the Maori Land Court has exclusive jurisdiction to constitute these authorized Maori trusts, which are ahu whenua; whanau; kai tiaki; putea; and whenua topu, as described above. ${ }^{22}$ However, like other trusts, they can also be constituted by will or deed, and given effect to by a court order, on the proviso that there is no conflict with the Act. ${ }^{23}$

It should be noted that the topic of Maori land trusts is very expansive, and as a result, it will be outside the scope of this article to consider all the matters pertaining to such trusts, and indeed to consider each type of trust in detail. Therefore, this article focuses on some key discussion points to highlight the significance and relevance of Maori land trusts in the New Zealand legal landscape. We therefore turn now to considering some of those five statutory forms of Maori land trust, concentrating in particular on the more common types of Maori land trusts, beginning with ahu whenua trusts.

\section{Ahu whenua trusts}

As mentioned above, this is the main form of trust where the total freehold interest in Maori land or General land owned by Maori is vested in a trust/ trustee by the Maori Land Court, and is utilized to

16. ibid 30 citing EJ Haughey, 'Some Aspects of Maori Leases' in Landlord and Tenant (1975) 341, 342

17. See <http://www.justice.govt.nz/courts/maori-land-court/about-us/past-present-future-of-the-maori-land-court>

18. ibid; Ruru (n 9) 1250.

19. ibid.

20. ibid; 'taonga tuku iho' translates as, inter alia, cultural property, or heritage $<$ http://www.maoridictionary.co.nz/search?idiom $=\& p h r a s e=\& p r o v e r b=\& l o a n$ $=\&$ keywords $=$ taonga + tuku + iho\&search $=>$

21. Hinde and others (n 12) 31 .

22. Te Ture Whenua Maori Act 1993, s 211.

23. Doug McPhail, 'Trusts Relating to Maori Land' in Richard Boast and others (eds), Maori Land Law (2nd edn, LexisNexis 2004 ) 163. 
promote and facilitate the use and administration of the land for those who are beneficial owners of the land. We will reference a number of cases to highlight some key matters with regard to this type of trust, beginning first with the general matter of governance.

\section{Governance}

Maori land trustees have the same obligations as other trustees, which means that they have a duty, inter alia, to act fairly and impartially between beneficiaries and to invest trust funds prudently. ${ }^{24}$ Specific rules pertaining only to Maori trusts are contained in the Te Ture Whenua Maori Act, although the equitable provisions set out in the Trustee Act 1956, and the body of trust law, also all apply to Maori trusts, unless they are excluded, or inconsistent with the provisions of the Te Ture Whenua Maori Act. ${ }^{25}$ As an example of specific provisions regarding Maori trusts, it has been recognized, specifically in relation to ahu whenua trusts, that payment of fees, honoraria, and other forms of remuneration to trustees:

is permissible in general terms, depending on the relevant circumstances in each individual case. ${ }^{26}$

Thus, a number of Maori trustee duties under ahu whenua trusts were set out by Harvey J, in the case of Re Tauhara Middle 15 Trust, as follows: ${ }^{27}$

Yet it should also be underscored that ahu whenua trusts have a defined purpose under section 215 of the Act [the Te Ture Whenua Maori Act 1993] and must operate according to the trust's particular trust order. While it can be desirable for trustees acting apparently with the support of their owners, their whänau and hapü, to repurchase traditional lands lost from communal control, they must do so consistent with their duties as ahu whenua trustees. Their principal duty is to obey their terms of trust. They have equally crucial duties of protecting the assets of the trust and acting prudently when investing trust funds. When so investing they must avoid hazardous or speculative ventures. This is because the custodianship of the existing corpus lands remains paramount.

Maori land trustees have the same obligations as other trustees, which means that they have a duty, inter alia, to act fairly and impartially between beneficiaries and to invest trust funds prudently. ${ }^{24}$ Specific rules pertaining only to Maori trusts are contained in the Te Ture Whenua Maori Act, although the equitable provisions set out in the Trustee Act 1956, and the body of trust law, also all apply to Maori trusts, unless they are excluded, or inconsistent with the provisions of the Te Ture Whenua Maori Act

What this case emphasized is the need for governors of Maori land trusts to have due regard for governance issues when carrying out their obligations, and in particular to have due regard to the following: ${ }^{28}$

- To exercise their responsibilities prudently;

- To address real and potential conflicts of interest when making decisions;

- To consider carefully the recommendations of professional advisors; and

- To understand that owners' resolutions are not binding on trustees.

More recently, the case of Parengarenga 3D v Slade ${ }^{29}$ also highlighted issues surrounding the very real importance of good governance, and illustrates the serious impact of poor governance. Parengarenga 3D comprises approximately 500 hectares, and had been committed to plantation forestry for about 30 years.

24. Ruru (n 9) 1254

25. McPhail (n 23) 164.

26. Re Pukeroa Oruawhata Trust BC200392563 24 December 2003, 5

27. Re Tauhara Middle 15 Trust 30/07/08 87 Taupo MB 10730 July 2008 at [70]; see also Rameka $v$ Hall [2013] NZCA 203 [5 June 2013] at [29].

28. Tama Potaka, 'Maori Land and Governance' [2009] NZLJ 106.

29. Parengarenga 3D v Slade 87 Taitokerau MB 4612 September 2014. 
An ahu whenua trust had been in place since at least 1987. The Maori Trustee had been the responsible trustee up until 2009, when the forest was harvested and the trust received over $\$ 1$ million New Zealand dollars. The Maori Trustee was replaced with seven trustees appointed by the Maori Land Court, four of which were subsequently removed by the Court in 2014. Between 2012 and 2013, the four former trustees received substantial payments from the Trust, equalling 700,000 dollars. At the time of this hearing, the Trust's bank account then held less than $\$ 14$.

This case concerned the alleged misappropriation of funds and an application for a Mareva injunction to secure Trust assets. ${ }^{30}$ While inevitably the case focused on questions applicable to Mareva injunctions, the discussions also illustrated very real issues regarding governance of the Trust, and the lack of any documentation to support payments to the former trustees, and their lack of responses, supported a good arguable case of equitable, if not, actual fraud. ${ }^{31}$ This meant that there were significant questions to be answered by those trustees ${ }^{32}$ in relation to their governance and their duties towards the Trust in question. On the face of it, the four former trustees appear, at the very least:

to have acted without any appreciation or understanding of the fiduciary obligations they owed to the trust. ${ }^{33}$

The losses attributed to the poor governance were so serious that they were reported in the national press. ${ }^{34}$

Therefore, ensuring good governance generally is key in managing Maori land trusts such as ahu whenua trusts, as with other types of trusts. However, governance may also be considered in more specific terms, including issues surrounding a number of trustees' duties, such as conflict of interest and improper behaviour for a trustee, to which this article now turns specifically in relation to such trusts.

\section{Conflict of interest}

Harvey J, in the case of Re Tauhara Middle 15 Trust, $^{35}$ addressed the issue of conflict of interest in relation to Tauhara Middle 15, which is Maori freehold land, with over 3000 beneficial owners, and the land is administered by an ahu whenua trust. There were a number of issues under discussion in this case, but our focus rests on the conflict of interest in this instance. The trustees of Tauhara Middle 15 Trust, in a complex number of transactions, purchased land via the Hikuwai Hapu Lands Trust. The allegations were raised in terms of the roles of the trustees, the competing interests of the various trusts, particularly Hikuwai, and the trustees' duties to the beneficiaries. ${ }^{36}$ The affected trustees sat on all three trusts involved in the purchase, and all three trusts were advised, or at least encouraged, by the same solicitors over the decision whether or not to enter the purchase. ${ }^{37}$ What was made clear by the Judge was that in matters relating to conflict of interest, it is not sufficient to declare that conflict at a meeting, nor is it sufficient to attempt to have it waived by the meeting of owners. ${ }^{38}$ The duty to ensure that there is no conflict of interest is far more strict than that. Indeed, a trustee's decision can even be 'tainted given the potential for and appearance of conflict'. ${ }^{39}$ It might however have been possible to have dealt with that potential or appearance of conflict by taking their solicitor's advice and applying for directions, which was not done.

Therefore, Harvey J concluded that the three affected trustees did place themselves in actual, or

\footnotetext{
30. ibid [15], [24], and [25].

31. ibid [27].

32. ibid [33].

33. Mark von Dadelszen, 'Obligations of those Governing Not-For-Profits-A Crisis to be Addressed?' [2015] NZLJ 113, 114.

34. 'Maori Trust's \$1 million is now \$15' The New Zealand Herald: Auckland (15 October 2014) <http://www.nzherald.co.nz/business/news/article.cfm?c_ id $=3 \&$ objectid $=11342473>$

35. Tauhara Middle 15 Trust (n 27).

36. ibid [82].

37. ibid [85].

38. ibid [89].

39. ibid.
} 
potential conflict of interest, or even the appearance of conflict, given their roles on the trusts in question. ${ }^{40}$ It is evident therefore that such Maori land trusts require strict adherence to the duty to ensure that there is no conflict of interest when trustees carry out their duties, and further:

the appearance of bias or conflict is sufficient since actual conflict need not be proved. ${ }^{41}$

The New Zealand Supreme Court, in the very recent case of Fenwick $v$ Naera ${ }^{42}$ addressed just this issue, inter alia, and specifically made reference to the issue of avoiding the appearance, and risk of conflict. The appeal concerned alleged conflicts of interest in relation to a joint venture, which was entered in to by the Whakapoungakau 24 Ahu Whenua Trust (commonly referred to as the Tikitere Trust), and two other Maori trusts. ${ }^{43}$

Three of the trustees were alleged to have conflicts of interest, on which the Supreme Court commented, although it has remitted the issue to the Maori Land Court for final decisions on the conflicts in light of the judgment, because the Supreme Court was not certain that it had all the relevant information. With regard to trustee Pirihira Fenwick, the Court held that she was interested or concerned in the joint venture arrangements because she was a beneficiary of one of the trusts, with an approximate 4.71 per cent share in that trust. As a result, she:

had a real and appreciable possibility of conflict between interest and duty and should not have taken part in the decision making process. ${ }^{44}$

With regard to trustee Tai Eru, the Court noted that his interest in the trust would be de minimus, in other words, there was likely 'no sensible possibility of conflict'. ${ }^{45}$ However, what was noted in the footnotes by the Supreme Court was that even a very small interest in a very large transaction could still raise the possibility of a conflict between interest and duty. However, in this situation, the Court was not sufficiently apprised of all the information pertaining to the joint venture to make a definitive finding on this point. Nonetheless, what this does speak to is the very serious obligations imposed upon trustees of ahu whenua trusts to ensure that conflicts of interest do not arise.

With regard to the third trustee, the late Winnie Emery, the Court held that while her husband was a trustee of one of the trusts involved, this did not render her as conflicted under section 227A of the Te Ture Whenua Maori Act 1993. ${ }^{46}$

In application to Mrs Fenwick, and possibly $\mathrm{Mr}$ Eru, the Court determined that under section $227 \mathrm{~A}(2)$, the former (and possibly the latter), should not have participated in the discussions surrounding the transactions, or in the voting. The section states the following: ${ }^{47}$

A trustee must not vote or participate in the discussion on any matter before the trust that directly or indirectly affects that person's remuneration or the terms of that person's employment as a servant or officer of the trust, or that directly or indirectly affects any contract in which that person may be interested or concerned other than as a trustee of another trust.

It had been argued that the breach of section $227 \mathrm{~A}(2)$ had no effect, given the ability for decisions to be made by a majority, however, the Court was in agreement with the Court of Appeal that all trustees, who take part in decision making, must 'bring to bear a mind unclouded by any contrary interest' ${ }^{48}$ Nor was

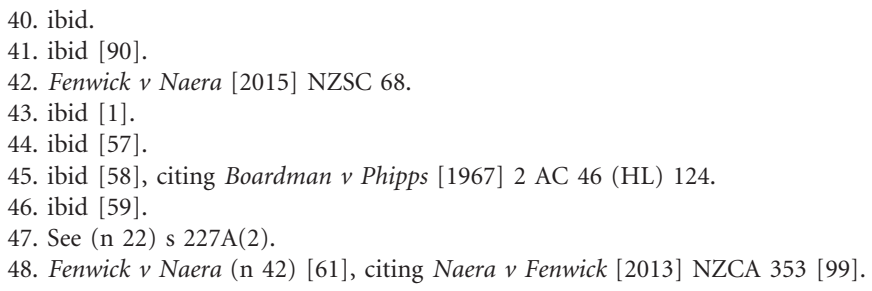


it any defence that their fellow trustees supported the decision. It is clear that section 227A provides that conflicted trustees should not participate in discussions on matters that affect their interests. There is an eminently sensible reason for such stringent requirements, and that is because: ${ }^{49}$

... a conflicted trustee must not participate in discussions is to remove the risk that the other decision makers may be influenced (either consciously or subconsciously) by a person with divided loyalties.

It is also important to note that lack of personal financial consideration will not negate the duty to avoid a conflict of interest. Neither Mrs Fenwick, nor Mr Eru was driven by such a consideration, but it was noted that this may only have been at a conscious level. In addition, beneficiaries are entitled to know that every trustee who considered, and voted in favour of the transaction, did so "without conflict of interest and the risk of being influenced by that conflict', 50 and importantly, whether or not that person was in fact influenced. ${ }^{51}$ Therefore, it matters not if the influence actually occurred, the mere fact that it could is the issue at hand. Further to this point, the Court concurred with the Court of Appeal that rules against conflicts, and section 227A, are 'designed with prophylactic effect'. ${ }^{52}$ In other words, 'to avoid the appearance, and risk, of conflict'. ${ }^{53}$ Such an effect applies: ${ }^{54}$

... both in terms of a conflicted trustee being influenced by the conflict (consciously or subconsciously) and of influencing fellow decision makers (again, consciously or subconsciously).
In relation to the notion of influence, whether conscious or subconscious, the Court pertinently noted that a court is not best placed to 'decide the existence and the extent of any influence'. ${ }^{55}$ The reality is that evidence pertaining to influence, or otherwise, is limited, and trustees will be required to 'reconstruct the decision-making process with the benefit of hindsight', which could falsify the process, and indeed, if the influence has been subconscious, then the trustees will not even be aware of it to express its impact. ${ }^{56}$

This, therefore, drives to the heart of the matter. Conflicts of interest can be insidious, and their effects may be wide ranging and highly damaging. As a result, the stringent burdens upon trustees to avoid conflicts of interest are well placed and much desirous to protect the interests of the beneficiaries. So, while it is evident that all trustees are duty bound to avoid such conflicts, ${ }^{57}$ contemporary evidence points to such duties being equally measured for trustees of ahu whenua trusts.

Avoiding a conflict of interest is clearly an important obligation for all ahu whenua trust trustees, but equity imposes numerous other duties on such trustees, including the requirement to ensure that their conduct is befitting a trustee. Unsatisfactory conduct can take a variety of forms, and we will consider some circumstances within ahu whenua trusts where trustee conduct has fallen under the spotlight.

\section{Unsatisfactory conduct}

In Scott $v$ Sullivan, ${ }^{58}$ the Maori Land Court heard a number of allegations made against two trustees of an ahu whenua trust, Virginia Sullivan and Mischele Cowan-Sullivan, including resiling from a unanimous

\footnotetext{
49. ibid [61].

50. ibid [62].

51. ibid.

52. ibid [63].

53. ibid [62], referring to Naera $v$ Fenwick [2013] NZCA 353 [99], and [101]-[102].

54. Fenwick $v$ Naera (n 42) [63].

55. ibid [64].

56. ibid.

57. ibid [69]-[70], referring to Andrew S Butler, 'Fiduciary Law' in Andrew S Butler (ed), Equity and Trusts in New Zealand (2nd edn, ThomsonReuters 2009) 476 and J Mowbray and others, Lewin on Trusts (18th edn, Sweet \& Maxwell 2008) [20-01].

58. Scott $v$ Sullivan 27 Takitimu MB 5 A20130008184 3 October 2013.
} 
trustee decision, and cultivating illegal drugs on trust property. In relation to the latter allegation, Harvey J dealt with this promptly. Quite simply, the conviction of an imprisonable offence for carrying out activities on trust land, of which she was a trustee, with the responsibility of acting in the best interests of the beneficiaries could hardly be construed as acting prudently or appropriately for a trustee. As such, her position was quite untenable. ${ }^{59}$ While this seems entirely proper to take such a firm stance, the Judge was in no way prepared to be lenient even with the trustee expressing regret as to her actions overall. This illustrates the very seriousness of the duties of trustees, including ahu whenua trustees, and the commitment by courts to observe such onerous duties.

With regard to the allegation of resiling from a unanimous decision to support a particular proposal, Harvey J noted that her actions resulted in the Trust becoming embroiled in litigation and incurring unnecessary legal costs. This was, in the Judge's view, conduct that was 'both imprudent and inappropriate'. ${ }^{60}$ If a trustee appears to be at an impasse with the other trustees, the duty is upon the trustees to seek direction from the court, which, in this case, was not undertaken. It mattered not to the court that the trustee acted with honest belief that her actions were correct, her actions were still judged as being unreasonable, because she acted contrary to legal advice and in defiance of earlier agreements. ${ }^{61}$ Therefore, it is evident that actions can still be unreasonable, even if a trustee genuinely believes them to be correct.

The Maori Land Court, in the ahu whenua trust case of Tunapahore 6 Block $v$ Powell ${ }^{62}$ confirmed that trustees have obligations to beneficiaries to administer the trust in accordance with general trust law, the Trustee Act 1956, the Te Ture Whenua Maori Act 1993, and the Maori Reservation Regulations 1994. In other words: trustees are subject to traditional trustee duties with the overlay of particular obligations arising from the context of Maori reservations. ${ }^{63}$

Grazing stock, growing crops, and removing timber for personal benefit, with no gain or benefit for the shareholders, by a trustee breached such obligations.

Failing to take steps to rectify issues with trust property may also result in a finding that trustees' actions resulted in unsatisfactory conduct. This issue was raised in the Court of Appeal in the case of Rameka $v$ Hall. $^{64}$ The question for the Court, inter alia, was whether or not the trustees in question carried out their duties satisfactorily in relation to a number of transactions involving significant amounts of money. In relation to the meaning of satisfactory conduct, the Court referred to Bramley $v$ Hiruharama Ponui Inc-Committee of Management-Hiruharama Ponui Inc, where the Court made reference to the following passage: ${ }^{65}$

Whether governance performance has been satisfactory or not must depend then on whether there is a clear and present apprehension of risk to the incorporation asset or to the wider interests of the incorporation shareholders as a result of action or inaction of the committee. It is not every unsatisfactory act or omission which should lead to removal, but those that go to the principles of the Act. To adopt any other approach, would lead to removal being the primary remedy available for any technical breach of the Act. We do not think that wholesale removal of Maori governance members is consistent with the principles of the Act or the intentions of the legislature.

While it was acknowledged that the case of Bramley involved a corporation, the provisions referred to above are applicable, and therefore the Court, in assessing the conduct of the trustees, would need to

\footnotetext{
59. ibid [27].

60. ibid [30].

61. ibid [31].

62. Tunapahore 6 Block $v$ Powell (2015) 118 Waioriki MB 150.

63. ibid [15].

64. Rameka $v$ Hall (n 27).

65. ibid [32], citing Bramley v Hiruharama Ponui Inc-Committee of Management-Hiruharama Ponui Inc (2006) 11 Waiariki Appellate MB 144 (11AP 144) [159]
} 
consider the impact of their actions on the beneficiaries and any 'apprehension of risk to the assets'. ${ }^{66}$

In relation to the mussel farm venture, the Court concurred with the lower courts that as the investment went sour, the trustees failed to act prudently. Rather the:

matter was simply allowed to drag on for too long, given the considerable sums of money involved. ${ }^{67}$

In order to have acted satisfactorily, the trustees could have taken a number of steps to discharge their duties, including expressing and recording their opposition to the ongoing investment of funds in to the venture. When looked at as a whole, the trustees should have done more to protect the trust assets, and the key factors in arriving at this conclusion were the magnitude of the sums involved and the extended period of inaction. ${ }^{68}$

In relation to one of the transactions, that of the Tauhara land purchase, a defence was raised that there was cultural significance in regaining the land, which reflects the added obligations on Maori land trustees over other types of trustees. However, the Court stated clearly that:

the motivation to regain land of cultural significance does not displace the duties on the trustees to act prudently. ${ }^{69}$

This was made most clear by Harvey $\mathrm{J}$ in the lower Court, albeit in relation to another area of land, where he noted: ${ }^{70}$

Much was made of the return of haukainga land for cultural and historic reasons. That desire is both understandable and laudable. Where owners have lost land through various means over time there is often a strong wish to recover such lands, especially those areas with iconic significance and where the opportunity presents itself for such restoration. But those objectives cannot override the trustees' principal duties of protecting the existing assets of the trust and their duty to act prudently.

Therefore, while culturally significant endeavours are laudable and understandable, Maori land trustees are still obliged to ensure that they are meeting their trustee obligations, as reflected in relation to this ahu whenua trust. Overall, therefore the Court of Appeal concluded that the trustees committed a series of breaches of their duties, causing substantial losses to the trust, thus their conduct was unsatisfactory. ${ }^{71}$

It is evident therefore that ahu whenua trustees have onerous obligations to meet under the requirements of various statutory and common law provisions, and this is equally the case with trustees of whanau trusts.

\section{Whanau}

It will be recalled from earlier in the article that these are share-managed type trusts, which were introduced under the Te Ture Whenua Maori Act 1993. Under them, land interests of the living or the deceased owner are vested in trustees, generally family members, and no further succession or fragmentation occurs. ${ }^{72}$ In other words, these trusts are familyorientated trusts that allow whanau to bring together their interests for the benefit of that whanau and their descendants. Often these trusts will operate under the umbrella of ahu whenua trusts or Maori incorporation. As long as the trust exists, there will be no succession, thus the land interests remain vested in the trustees. However, should a beneficiary die, the Maori Land Court may determine a successor, as this may assist the trustees to maintain the whakapapa. ${ }^{73}$

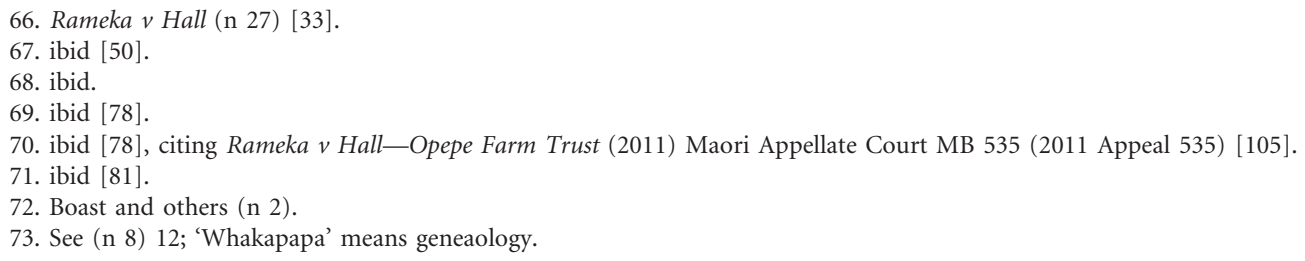


As is apparent therefore, such trusts are strongly focused on whanau, and the Act sets out their purpose as follows: ${ }^{74}$

The land, money, and other assets of a whanau trust shall be held, and the income derived from those assets shall be applied, for the purposes of promoting the health, social, cultural and economic welfare, education and vocational training, and general advancement in life of the descendants of any tipuna (whether living or dead) named in the order.

Since their introduction in July 1993, these trusts have become a popular vehicle to prevent fragmentation of interests in Maori land. ${ }^{75}$ The benefits for Maori in creating whanau trusts are therefore clear, however, what some cases reveal is a tension between whanau and trustees, and indeed divisions of whanau themselves. We will explore some cases to assess the courts' ability to acknowledge Maori beliefs and practices in alignment with recognizing the applicability of the relevant law with regard to whanau trusts.

\section{Benefits of whanau trusts}

The relevance of whanau trusts in the administration of Maori land was illustrated in Re Hauai. ${ }^{76}$ In this case, the applicant wished to gift all of his interests in Hauai 2D5, 8, and 9 to his two daughters. This gift would effectively exclude his son Duane, his deceased son Viva, and all of their descendants from any interests in the Hauai lands. The proposed gifting was under section 164 of the Te Ture Whenua Maori Act 1993, which states: ${ }^{77}$

The court may, in accordance with this section, make a vesting order for the transfer of any Maori freehold land or any undivided interest in any such land to and in favour of any person or persons to whom that land or interest may be alienated in accordance with the provisions of Part 7.

Ambler J made explicit reference to the discretion available to the Court with regard to applications under this section, which reflects the very real considerations of all parties when dealing with Maori land and interests: ${ }^{78}$

... Interests in Māori land are not synonymous with interests in general land. They carry with them the contingent 'interests' of the whanau, hapu and descendants of the owners. (I use the word 'interests' cautiously as I am not suggesting that they amount to either legal or equitable interests in the land. The interests may only be in the processes under the Act.) Owners wishing to transfer interests may need to first traverse the objections of their whanau, hapu and descendants.

In assessing the merits of a transfer the Court must measure the circumstances of the case against the intentions and objectives of the Act as set out in the Preamble, section 2 and section 17. The proposed transfer may give rise to tension between the objectives of retention of the land and use, management and development of the land...

... Where a transfer is contentions or opposed the Court should examine the underlying rationale for the transfer. What is the practical purpose? How does the transfer promote the 'use, management and development' of the land? Does the transfer carry with it obligations on the transferee? If so, how are they to be given effect to? Is there an alternative to outright alienation, such as creating a life interest only or vesting in a whanau trust? Ultimately, where the transfer contravenes the intentions and objectives the Act, the Court may decline to order the transfer...

... This goes to the heart of the twin objectives of retention and utilisation of Māori land that are sometimes in conflict...

\footnotetext{
74. See (n 22) s 214(3).

75. Boast and others (n 2) 183.

76. Re Smith - BC201560816 99 Taitokerau MB 20031 March 2015.

77. See (n 22) s 164(1).

78. Smith (n 76) [5], citing Barnes - Te Horo 2B2B2B Residue (2008) 125 Whangeri MB 11 (125 WH 11) [27]-[31].
} 
Therefore, the Court's assessment of the issues at stake was fundamental in coming to a decision as to whether transfers of land should occur because of the relationships, obligations, legal requirements, and interests involved. The applicant in this case saw his daughters as having the right skills to administer the land in the future, and His Honour had no doubt that he was correct in this assessment, however, His Honour asserted that: ${ }^{79}$

... absolute gifting as proposed is ... a very blunt legal tool which will exclude half of his children and their descendants from Hauai lands.

The applicant's remaining son had given his permission for such a gift to take place, as he was of the view that his sisters would not alienate the land from the family, however, Ambler J reflected that an absolute gift was not the most appropriate course of action when taking in to consideration whanau matters. In his view, the best legal approach would be to create a whanau trust, which assist the applicant in achieving his aims for his whanau. The whanau trust could include express provisions to accommodate the applicant's kaupapa ${ }^{80}$ for the land. Indeed, such a trust would enable the daughters to have all the powers necessary to administer the land, but without excluding any of the applicant's descendants.

One daughter expressed dissatisfaction with such a trust because she asserted that it would lead to ongoing disputes with the deceased son's widow and his children. Ambler J, however, asserted that the Te Ture Whenua Maori Act 1993 expects Maori to look beyond such things and instead she should focus on the late brother's children and their descendants, thus reflecting the importance of the significance of the Act in Maori land matters. As a result, the Judge concluded that the proposed gifting would contravene the kaupapa of the Act, thus section 164 could not properly be invoked. He also noted that he could not insist on the applicant agreeing to a whanau trust, but equally, he was of the view that the application must be dismissed because it was not in the best interests of the whanau. ${ }^{81}$

Thus, while some members of the whanau believed that an absolute gift to be the most appropriate method of administering land, the Court could not reconcile the opposing purpose of the Act and the purpose of the applicant. Therefore, this case illustrates the very clear tensions that may arise in such circumstances and how a court is able to align cultural, holistic, and legal requirements in an objective and appropriate manner with regard to the application of whanau trusts.

Tensions between whanau were a key consideration in two very recent cases before the Maori Land Court, where the Court had to consider the level of dysfunction within a whanau trust, and then whether partial termination of the trust would be an appropriate course of action to take.

\section{Whanau trusts and dysfunction}

In the first case, that of Green $v$ Trustees of Te Kou Tiaki and Tangi Ataahya Green Whanau Trust, ${ }^{82}$ the Court had to determine if there was sufficient grounds to terminate the trust partially. In 2004, an order was made to vest land interests of 12 persons in a Whanau trust. As the Court noted, the objective of the Whanau trust is to: ${ }^{83}$

... provide for the management of the Trust property to the best advantage of the beneficiaries, to make provision for any special needs of the beneficiaries, to represent them on all matters relating to the shares and to the use and enjoyment associated with those.

\footnotetext{
79. ibid [8].

80. 'Kaupapa'—purpose or plan <http://www.maoridictionary.co.nz/word/2439>

81. Smith (n 76) [8]-[11].

82. Green v Trustees of Te Kou Tiaki and Tangi Ataahya Green Whanau Trust 92 Waiariki MB 18317 March 2014.

83. ibid [21].
} 
Thus the objective is to ensure the best interests of the beneficiaries. The Court further noted that the purpose of this trust was to bring together all the interests of the Te Kou Tiaki and Rangi Ataahua whanau. With the death of one of the trustees, the trust has not been in a position to best manage the interests of the beneficiaries because the trustees had been inactive. Further, there was discord between the applicant and the trustees. The applicant believed that because he was their elder, he did not have to listen to them, and the Court was concerned that he would attempt to do what he wished and ignore the trustees. He was determined to have his shares released from this trust, but the Court had to weigh that desire against the reason as to why he wants to terminate the trust. It was noted, inter alia, that the applicant was of the view that the trustees had not utilized the Trust property to the best interest of the applicant; that the trustees had been working against the applicant; there was a lack of involvement by the trustees in the Trust; and that due to the dysfunction of the Trust, he cannot work with the trustees. ${ }^{84}$

The Court noted that any termination would have an impact on the remaining beneficiaries adversely because there would be a loss of voting power, and some potential development, now that the trustees were active once again. There was also overwhelming beneficiary and trustee opposition to the partial termination.

Also of note to the Court in their determination was the consideration a Court might have when assessing the merit of a partial termination: ${ }^{85}$

a. the Preamble, s 2, and other matters listed in s 17 [Te Ture Whenua Maori Act 1993], including the extent to which partial termination achieves better retention, use, development and control of the land in accordance with the fundamental principles and purposes of the legislation;

b. the purposes of the whannau trust;

c. the extent of beneficiary and trustee consent; d. the impact of any termination on the remaining beneficiaries and the trust; and

e. any evidence of dysfunction by the whānau trustees to justify the Māori Land Court's intervention.

While the Court acknowledged the dysfunctional relationship that existed between the applicant and the trustee, when weighed against the other factors, and taking in to account the Preamble, sections 2 and 17, the order for a partial termination was not granted. It was evident that divisions were entrenched in the whanau, but it would not be in the interests of the applicant or the other beneficiaries to allow the application. The applicant could not achieve the objectives he set for his shares, and he provided no sufficient reason to warrant such a course of action. Neither was there any credible evidence as to future development options.

What this decision therefore indicates is that while whanau may be divided, or there may be some dysfunction within the whanau or trust, the Te Ture Whenua Maori Act, the Courts, and whanau trusts, operate to ensure the benefit for the totality of the whanau, so the greater good of the whanau is given weight in preference to individual desires, which is a reflection of the strength of whanua relationships.

The 2015 Maori Land Court case of Moa Larkins v Hurae and Ngawiata Whanau Trust ${ }^{86}$ eloquently expressed the notions of whanau, and in particular, this case focused on the concept of whanau trusts and unity, even in the face of dysfunction.

The whanau trust was constituted for the benefit of the descendants of Jack and Ngawaiata Larkins. At the time of the application, there were three generations of descendants who were beneficiaries of the whanau trust, who would be impacted by its partial termination. Moa Larkins, the eldest of the seven children of Jack Larkins, sought a partial termination of this trust. The trust was established in 2005 to bring together the various Maori land interests to which Jack,

84. ibid [10] and [13]-[14]

85. ibid [16] citing Moa Harris Larkins or Moananui Larkins v Trevor Wi Kaitaia \& Ors [2013] MAC MB [159].

86. Moa Larkins v Hurae and Ngawiata Whanau Trust 94 Taitokerau MB 12015 January 2015. 
and his siblings, were entitled. Moa Larkins gave evidence that he had not seen 'eye to eye' with his siblings for many years, and while the trust was supposed to unify the whanau, in reality, it had not resolved their underlying differences. He expressed concern that the Trust was not performing satisfactorily, thus he sought to remove the interests in Waihou Hutoia D2A from the Trust. ${ }^{87}$

Interestingly, the applicant acknowledged that removing Waihou Hutoia D2A interests would in fact not address the alleged dysfunction within the Trust, as other interests contributed by Moa would remain in the Trust. He also could not provide information as to what he wished the whanau trust to do with Waihou Hutoia D2A interests, and merely argued that he wished those interests to be returned. The real issue was the relationships between the siblings, not the Trust itself. ${ }^{88}$

The Court determined that a partial termination of the Trust would not in fact achieve a better retention, use, development, and control of the Waihou Hutoia D2A land. Whether the land interests were held by the whanau trust, or by Moa, would not make any difference to the ability of the member of the whanau to build on that land. Further, there was no evidence before the Court to persuade it that the functioning of this whanua trust was an impediment to any member of the whanau building on that land. ${ }^{89}$

The next consideration was the purpose of the whanau trust. This was set out in the objects clause, and reads: $:^{90}$

To administer and preserve the interests of the whanau and to use the income derived from those interests to be applied for the purposes of promoting health, social, cultural and economic welfare, education, and vocational training and general advancement in the life of the beneficiaries of the whanau trust.

It was noted that this purpose is virtually the same for all whanau trusts constituted under the Act, and the Court could find nothing in the purposes that would suggest any form of exception should be made for the interests that Moa contributed. What needed to be emphasized was the purpose of this whanau trust. That was to bring some unity to the whanau who had received different interests from their parents over the years. ${ }^{91}$ In reality, the partial termination of the trust by removing the Waihou Hutoia D2A interests would 'contravene the very purpose of and rationale for the trust'. ${ }^{92}$ The removal of those interests would, in the Court's view, be a clear and substantial detriment to the other beneficiaries. ${ }^{93}$

Turning finally to the underlying issue of the dysfunction within the whanau trust, the Court noted that there was very limited evidence of actual dysfunction. ${ }^{94}$ In reality, this was not a case 'where a whanau trust has been so dysfunctional that it is beyond redemption'. ${ }^{95}$ Rather, Moa had had a change of heart and wished to retrieve the interests in that specific block of land to which he had contributed the whanau trust. In such circumstances:

a change of mind in the face of such opposition is not enough to justify removing interests from the whanau trust. $^{96}$

This notion of dysfunction was finally put to bed when the Court asserted that Moa would remain as a trustee and a beneficiary on the trust, thus a partial termination would not resolve any alleged dysfunction.

87. ibid [21]

88. ibid [22].

89. ibid [38].

90. ibid [39].

91. ibid.

92. ibid.

93. ibid [41].

94. ibid [42].

95. ibid [43].

96. ibid. 
What this case therefore coherently demonstrates is the Court's ability to recognize the underlying concepts and meanings behind a whanau trust, and to ensure that their reasoning reflects and underpins those concepts and meanings to reflect a trust's true purpose. As Ambler J affirms, the partial termination would be a retrograde step for this whanau, and would contradict the original kaupapa that the siblings embraced, that of unifying the whanau by bringing the land interests together. ${ }^{97}$ Such unity:

does not grow on its own, it requires steady and consistent fostering by members of the whanau, ${ }^{98}$

and that reflection of the purpose of this whanau trust was explicitly recognized by the Court, and the Court acted for the benefit of the whole, not the individual.

Overall, therefore, one can see how courts, in regard to whanau trusts, are able to give full acknowledgement to Maori beliefs and practices, and apply the law practically to be able to resolve issues arising from such trusts.

We now turn lastly to the matter of whenua topu trusts, and some key points in relation to this type of Maori land trust.

\section{Whenua topu trusts}

It will be recalled from earlier, that these trusts are similar to the ahu whenua trusts in that they are landmanagement trusts, but whenua topu trusts operate to facilitate the use and administration of the land in the interests of iwi ${ }^{99}$ or hapu, ${ }^{100}$ as opposed to those with a beneficial interest in the land. ${ }^{101}$ Whanau, putea, and kaitiaki trusts can operate under the umbrella of these trusts. Almost anything that is legally in order can be achieved under this trust. However, sale of land can only occur through complying with very strict rules that ensure the kaupapa of the Act is met, in other words, the retention of Maori land under Maori ownership. A number of trusts do not permit sale of land entirely. ${ }^{102}$

The Maori Land Court has exclusive jurisdiction to establish such trusts, and with respect to the trusts that it establishes and monitors, a jurisdiction equivalent to that of the High Court with respect to trusts generally. ${ }^{103}$ Whenua topu trusts, as a form of trust, have been available since the enactment of the Te Ture Whenua Maori Act 1993, and while in existence, no person will become entitled to succeed to any interest vested in the trustees for the purpose of the trust. $^{104}$

In the Maori Land Court case of Taueki v McMillan, ${ }^{105}$ Harvey J referred to the benefits of utilizing such a trust in an administrative context for the effective management of a trust. His Honour recommended that the trustees and the beneficiaries consider the device of whenua topu trusts, and noted that such a trust may be established in the Court, is satisfied that it would 'promote and facilitate' the 'use and administration' of the land in the 'interests of the iwi or hapu'. ${ }^{106}$

Section 216(3) sets out the requirements of such application for creating this type of trust:

An application for the constitution of a whenua topu trust under this section-

a. shall be made in respect of all the beneficial interests in 1 block or in 2 or more blocks of land; and

b. may be made by or on behalf of any of the owners or the Registrar of the court.

97. ibid [45]

98. ibid.

99. See (n 4).

100. See (n 5).

101. Boast and others (n 2); See (n 22) s 216(2).

102. See (n 8) 9-10.

103. Pirika v Eru (2013) MAC MB 12728 March 2013 [28], referring respectively to the Te Ture Whenua Maori Act (n 22 ) ss 211 and 237.

104. Re Estate of Rachel Ngeungeu Zister 63 Waikato Maniopoto MB 28627 September 2013 [95], also referring to (n 22) ss 216(2) and 216(6).

105. Taueki v McMillan BC201463687 2014.

106. ibid [120], citing (n 22) s 216(2). 
Section 216(4) states:

The court shall not grant an application made under this section unless it is satisfied-

a. that the owners of the land to which the application relates have had sufficient notice of the application and sufficient opportunity to discuss and consider it; and

b. that there is no meritorious objection to the application among the owners, having regard to the nature and importance of the matter.

In other words, the exercise of the Court's jurisdiction requires that under section $216(4)$, sufficient notice and opportunity must be given for discussion tests to be satisfied, as well as there being no laudable objections to such a trust being created. ${ }^{107}$ Once such a trust is created, the assets of the trust are held in accordance with Maori community purposes for the general benefit of the iwi. ${ }^{108}$ His Honour also gave examples of the following whenua topu trusts: ${ }^{109}$

a. the Pakaitore Whenua Topu Trust created by the tribes of Whanganui to receive firstly Pakaitore (Moutoa Gardens), the Whanganui Courthouse lands and in due course, the interests of the tribes of Whanganui in the Kaitoke Prison and the Lismore State Forest;

b. Puke Ariki and Bayly Road whenua topu trusts established for the benefit of the Ngati Te Whiti hapu of Te Atiawa in Taranaki to receive lands from private parties;

c. Rotoehu Forest whenua topu trust created to receive former Crown forest licensed lands as part of the Ngati Awa settlement for the benefit of two particular hapu, Ngati Hikakino and Ngai Te Rangihouhiri II.
Therefore, all the Court needs to be concerned with, in considering whether to create such a trust, is whether the tests for the creation of such a body have been satisfied. He noted, importantly, that the benefit of such a trust is that it does not require the continuation of succession, and thus the subsequent fragmentation of interests. ${ }^{110}$ This clearly is of advantage for Maori interests within Maori land, thus it is understandable why courts may promote their creation, where applicable to do so. However, as his Honour noted, it is for the beneficiaries and trustees to consider the merits of such a trust. ${ }^{111}$

As is evident with whenua topu trusts, the interests of iwi must be represented, and the very recent case of Te Runanga o Ngati Maru (Taranaki) Whenua Topu Trust ${ }^{112}$ discussed just this issue, which is our final matter for discussion on Maori land trusts.

It was alleged that the trustees failed to represent the interests of Ngati Maru on all matters by, inter alia, failing to act as representatives for the iwi with local council, the Department of Conservation, and other third parties. One of the objects of the Trust was to represent the interests of Ngati Maru on all matters relating to the land and including use of the Trust's facilities. ${ }^{113}$

As Harvey J noted, if the trustees were not conferring with their beneficiaries on a regular basis, then it would be difficult to see how they were able to fulfil this requirement satisfactorily. It is obvious that where trustees are obliged to represent interests of a tribe, 'consultation with the constituents on a regular and continuing basis is necessary'. ${ }^{114}$

His Honour did acknowledge that the trustees had tried to meet their obligations oftentimes challenging circumstances, however, trying to meet obligations is not the same as actually meeting them. Where there are difficulties in meeting such obligations, the onus is on the trustees to seek direction from the court,

107. ibid [121]

108. ibid, referring to (n 22) ss 216(5) and 218.

109. ibid [122]

110. ibid [123]

111. ibid [123].

112. Re Runanga o Ngati Maru (Taranaki) Whenua Topu Trust 335 Aotea MB 127 March 2015.

113. ibid [76]-[78].

114. ibid [78]. 
which they had been advised to do in writing as well as in open court. ${ }^{115}$ It was therefore, "inexplicable that the trustees did not seek directions in such circumstances'. ${ }^{116}$ Generally speaking therefore, on this point, the trustees had not been fulfilling their obligations to their beneficiaries.

What this speaks to is the continued stringent duties imposed on Maori trustees regardless of the type of Maori land trust, and even if trustees face challenging circumstances, this does not discharge their obligations. To try is not a guarantee of success when it comes to trustee obligations to iwi. It is evident that in the face of challenges, a court expects to see positive action being taken by trustees to resolve the issues, even if that means turning to the court to seek direction.

\section{Concluding remarks}

It is evident, even from this brief foray in to Maori land trusts, how valuable such trusts are in the unique New Zealand legal landscape in recognizing and protecting Maori interests. To a large extent, the connection to Maori:

identity is manifested today through their ownership in Maori land. Therefore, the legislation applying to Maori land is important in respect of the connection of people to their land. ${ }^{117}$

Nonetheless, trusts applying to Maori land are subject to the general law of trusts, either through common law requirements, or under the Trustees Act 1956, in the same way as other types of trusts, which may be stated as: ${ }^{118}$
[A]n equitable obligation binding a person (who is called a trustee) to deal with property over which he has control (which is called trust property) for the benefit of persons (who are called beneficiaries) of whom he may himself be one and any one of whom may enforce the obligations.

However, as we have seen, Maori land trusts and trustees are also subject to specific rules and obligations contained in the Te Ture Whenua Maori Act 1993, as well as trust instruments, and the common law applying specifically to such trusts. It is evident from the cases that we have discussed that the courts endeavour to recognize the rights of the beneficiaries and the obligations of the trustees in a manner that can best facilitate the retention and utilization of such lands in a way that will align most appropriately with Maori culture and beliefs. The case law to which we have referred illustrates that the kaupapa of the Te Ture Whenua Maori Act 1993 is the promotion and retention of Maori land within the hands of owners, their whanau, and hapu, and in doing so, facilitates the most beneficial occupation, development and utilization of that land for the benefit of the owners, their whanau, and hapu. ${ }^{119}$

Therefore, Maori land trusts are a fundamental part of New Zealand legislation and New Zealand indigenous culture, and of value, generally, as a relevant management tool for much Maori land.

Maori land trusts are a fundamental part of New Zealand legislation and New Zealand indigenous culture, and of value, generally, as a relevant management tool for much Maori land

Juliet Chevalier-Watts, Associate Dean Research, Senior Lecturer in Law, Te Piringa-Faculty of Law, University of Waikato.E-mail: julietcw@waikato.ac.nz

115. ibid [79]

116. ibid.

117. Te Hunga Roia Māori o Aotearoa (New Zealand Māori Law Society Incorporated) Submission on review of Te Ture Whenua Māori Act 1993 14 June 2013 [2.1]

118. Boast and others (n 2) 164, citing Sir Arthur Underhill and David J Hayton, Underhill: Law Relating to Trusts and Trustees (13th edn, Butterworths 1979) 1. 119. See (n 8) 2. 